\title{
Channel characteristics and planform dynamics of the lower Niger River, Niger Delta Basin (1985-2015)
}

\author{
Tombra Akana ${ }^{1}$, Olubunmi Adeigbe ${ }^{2}$ \\ ${ }^{1}$ Pan African University and Niger Delta University, Department of Geology; Nigeria; \\ e-mail: brossatombra@gmail.com (corresponding author); ORCID ID: 0000-0002-4750-8843 \\ ${ }^{2}$ University of Ibadan, Department of Geology; Nigeria; e-mail: olukris2009@gmail.com; ORCID ID: 0000-0002-5305-5713
}

(C) 2019 Authors. This is an open access publication, which can be used, distributed and reproduced in any medium according to the Creative Commons CC-BY 4.0 License requiring that the original work has been properly cited.

Received: 8 May 2019; accepted: 17 December 2019; first published online: 30 December 2019

\begin{abstract}
This study used repeat satellite imagery and Geographic Information System analysis to assess the planform dynamics along the length of the lower Niger River Valley from Onitsha city to the coast between 1985 and 2015. The aim is to understand the altered dynamics and its plausible causes in this data-poor region. Analyses revealed that the Niger River has undergone change corresponding to enhanced instability in terms of an increased rate of erosion. In the study area, a change was observed from 3.7\% of deposition in the first 10 years (1985-1995) to $3.9 \%$ of erosion in the next 10 years (1995-2005) and $4.7 \%$ of erosion in the last 10 years (2005-2015). Total erosion over the 30-year period (1985-2015) in the delta was calculated on $4.8 \%$. The river channel has migrated toward the east in the upper and lower reaches while the mid-section of the channel is migrating towards the west. The east river bank is observed to be more unstable compared to west bank line through the study period. The maximum shifts identified were $3.35 \mathrm{~km}$ of deposition in 10 years (1985-1995), $3.31 \mathrm{~km}$ of erosion in the next 10 years (1995-2005), and another substantial erosional shift of $3.35 \mathrm{~km}$ in the next 10 years (2005-2015). Avulsion rates gradually moved from $-42.1 \mathrm{~m} \cdot$ year $^{-1}\left(1985-2005\right.$, segment F) to $100.2 \mathrm{~m} \cdot$ year $^{-1}(1985-1995$, segment D), large deposition in the first 10 years. Total avulsion rates of the delta in the last 30 years (1985-2015) has pointed on erosion $\left(-2.2 \mathrm{~m} \cdot\right.$ year $\left.^{-1}\right)$. The altered dynamics observed would likely threaten the future of the fragile lower river system environment and raise concerns for operators with infrastructure within the Niger Delta.
\end{abstract}

Keywords: delta, channel dynamics, avulsion, human activities, GIS, Niger River Valley

\section{INTRODUCTION}

Channel planform geometry has been well studied by Schumm (1963) and Snow (1989). Leopold et al. (1964: 453-468) proposed that the degradation of river channels can be attributed to the alterations in its hydrologic regimes, and its channel planform pattern being influenced by the character of the hydraulic regime. These regimes directly influence the total sinuosity and channel character of the river. Bridge (2003: 147-155) suggested that the total sinuosity is a combined measure of channel segment sinuosity and the degree of braiding. Channel sinuosity is controlled by channel gradient, sediment load, resistance to lateral erosion of a river and stage of valley development and the structural characteristics of the area through which it flows (Prasad 1982). Ward et al. (2000) inferred a rapid change in river morphometry during the Permian-Triassic transition from evidence reflected in sedimentary facies and channel sinuosity in the Karoo River Basin of South Africa. According to Murgatroyd \& Ternan (1983), the relationship between channel sinuosity and valley gradient for non-forested reaches of the river indicated decreased sinuosity resulting from afforestation. River channel changes such as bank erosion, downcutting, and bank accretion are natural processes for a river. 
However, regional developments such as sand mining, settlement, development of transport networks, infrastructure construction on the riverbank, artificial cutoffs, bank revetment, reservoir construction and land use alterations change the natural geomorphologic dynamics of rivers (Surian 1999, Kesel 2003, Surian \& Rinaldi 2003, Batalla et al. 2004, Vanacker et al. 2005, Wellmeyer et al. 2005). Such human activities may even become stronger forces for change than natural threshold events such as large floods and droughts. The resulting channel changes cause various environmental and socioeconomic consequences in terms of navigation, loss of riparian land and infrastructure, flood hazards, and the alteration of aquatic and riparian ecosystems. The purpose of this paper is the presentation and visualization of the anabranching planform geometry and evaluation of avulsion rate behavior of the confined meandering section of the Niger River and to relate the channel-avulsion rate of this river to basic hydrologic and geomorphic controls. Although the new data presented here are clearly of scientific interest to those seeking to understand the dynamics of meander migration, they are also significant to practical issues such as predicting channel-avulsion rates for engineering and planning purposes.

The Niger River, which is Africa's third-longest river and exceeded only by the Nile and Congo rivers, is a relatively pellucid river, carrying only a tenth as much sediment as the Nile, because its headwaters lie in ancient rocks that provide little silt (Reader 2001). It is over $4,180 \mathrm{~km}$ (2,500 miles) long and has a crescent shape. It travels through Guinea, Mali, Niger, on the border with Benin and then through Nigeria. Finally, it reaches the sea via the Niger Delta in Nigeria which borders the Atlantic Ocean at the Gulf of Guinea (Fig. 1). The Niger River is observed to flood annually; this begins in May, peaks in September and finishes by December. These seasonal floods make the delta quite productive for both fishing and agricultural activities. An unusual feature of the river is the Inner Niger Delta, which forms where its gradient suddenly decreases and results in a region of braided streams, marshes and lakes the size of Belgium (Reader 2001). The most important tributary of the Niger in Nigeria is the Benue River, which merges with the river at Lokoja city in south-central Nigeria. The total volume of tributary flow in Nigeria is six times higher than the inflow volume into Nigeria, with a flow near the mouth of the river standing at $177.0 \mathrm{~km}^{3} \cdot \mathrm{year}^{-1}$ before the 1980s and $147.3 \mathrm{~km}^{3} \cdot \mathrm{year}^{-1}$ during the 1980s (FAO 1997). Over time, upstream erosion by the lower Niger River has resulted in the stream capture of the upper Niger by the lower Niger (McKnight et al. 2005).

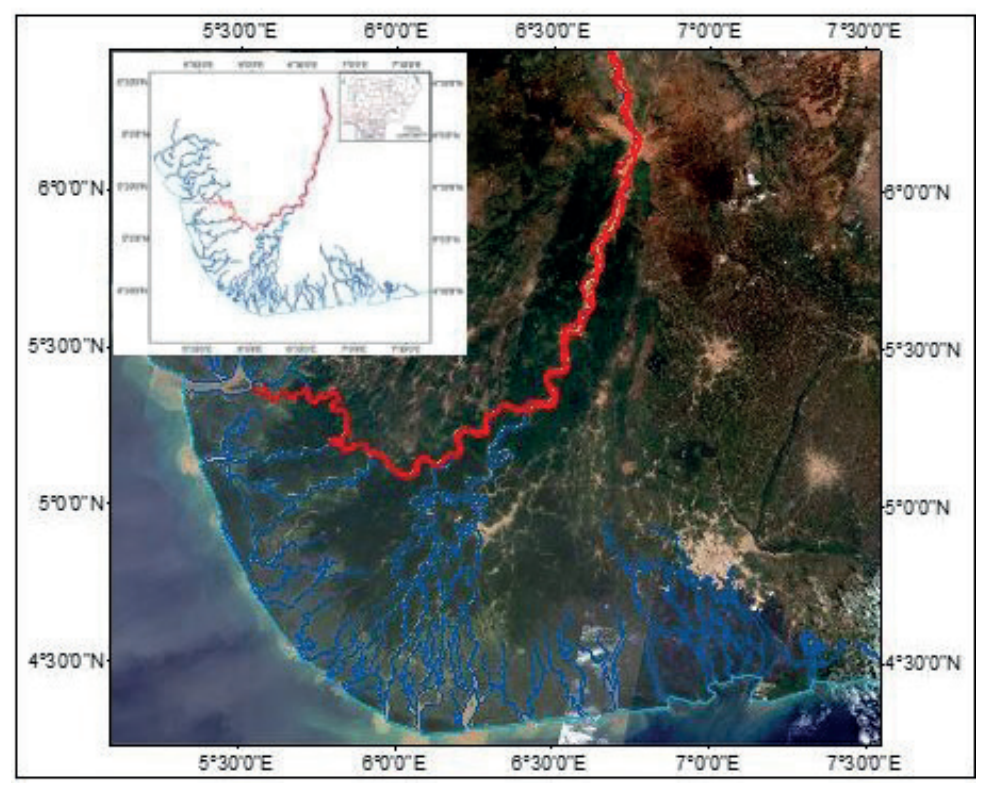

Fig. 1. Satellite imagery of the Niger Delta with the River Niger, main channel highlighted in red 


\section{METHODOLOGY}

\section{Data and image processing}

Satellite images from 1985, 1995, 2005 and 2015 (Landsat TM - resolution $30 \mathrm{~m}$ ) covering the study area, were used for assessing planform changes in the channel over a period of time. All images were from the month of October. All datasets were geometrically corrected and resampled to bring them to the same scale (Lillesand \& Kiefer 2000).

\section{Channel characteristics}

Channel planform changes were studied by the channel morphology, river bank line position, length, area, sinuosity and braiding intensity analyzes. In order to assess the characteristics, the methods used by Winterbottom (2000) and Tiegs \& Pohl (2005) were utilized. The river channels were digitized in ArcGIS software as one continuous polygon for each year at a scale of 1:30,000. River channels were defined as elongated areas where streamflow occurred with sufficient frequency, force, and duration to preclude the presence of vegetation such that $90 \%$ or greater of the area is bare of ground or water (Gurnell 1997, Winterbottom 2000, Tiegs \& Pohl 2005).

\section{Changes in morphology}

The digitized river channel of 1985 was divided into fifteen equal segments for the Niger River (A-O), $22 \mathrm{~km}$ length each (Fig. 2). A combined map was prepared by superimposing the digitized river channels of all years to assess changes during different time periods. Changes in morphology were assessed by visual inspection of the digitized channels. Our typology was mainly based on the methods proposed by Goswami et al. (1999) for anabranching planforms. It was used as a base to classify the observed geomorphological changes. The different types of planform changes were recognized by the registration of changes such as channel width and length and also the progressive shifting of the meander bends.

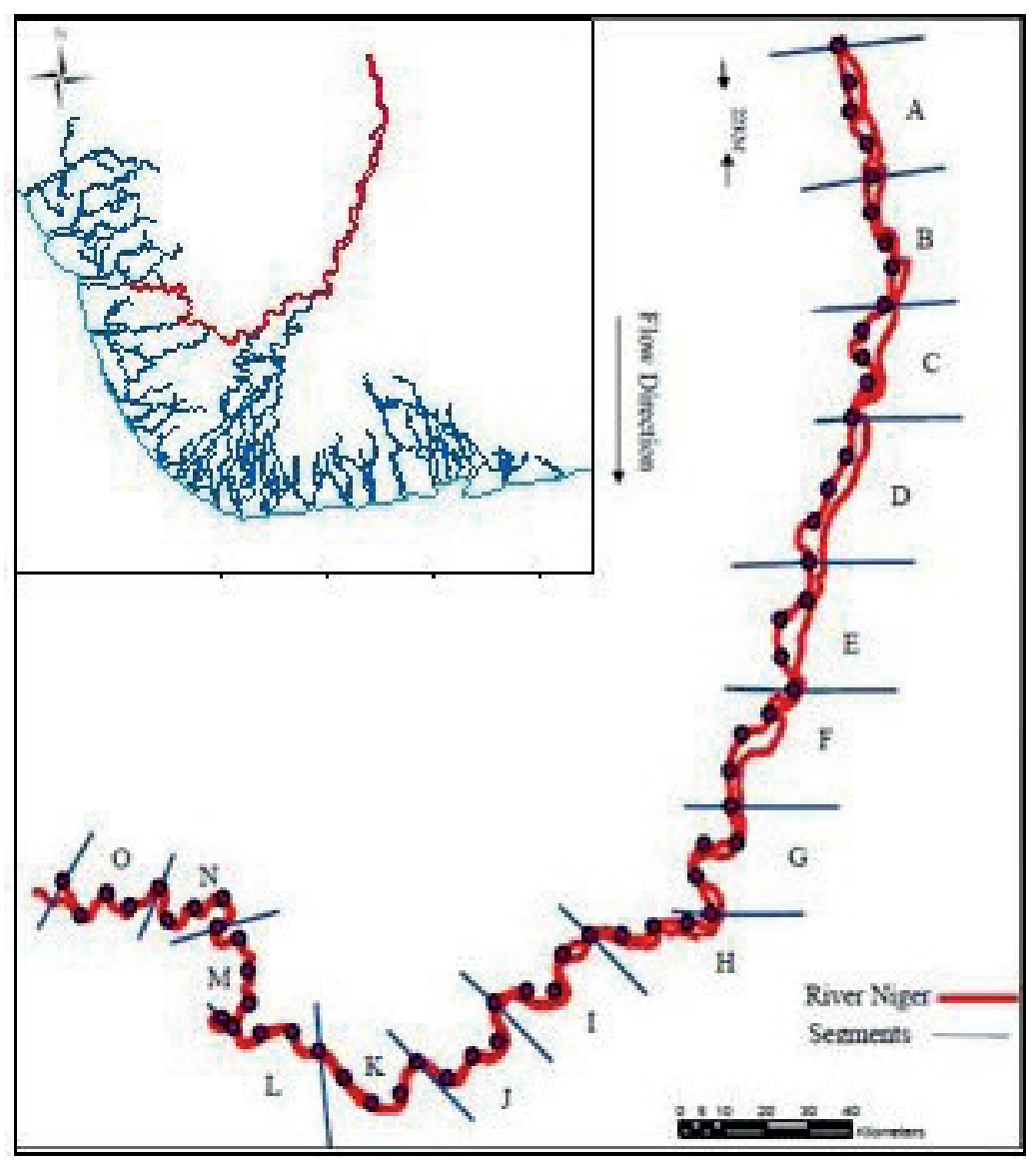

Fig. 2. Transverse sections and investigated segments of the River Niger 


\section{Changes of the channel features}

Channel length was measured along the line equidistant and parallel to the left and right river banks of the channel polygon. The active channel area was determined for each polygon in GIS software, excluding vegetated mid-Channel Islands as adopted by Tiegs \& Pohl (2005). The line used to determine the channel length. It was also used to measure sinuosity (channel length/straight-line valley length). The channel length, area and sinuosity were determined for the entire river channel, for all the assessment periods as well as for each investigated segment.

\section{RESULTS}

\section{Planform changes in the Niger Delta}

During the assessment periods, five cases of the straightening of the river course due to bank detachment occurred. In segment A (2005-2015), the straightening decreased the length of the river by $2.62 \mathrm{~km}$ (10\%), segment B (1985-1995; 2005-2015) by $2.2 \mathrm{~km} \mathrm{(10 \% )} \mathrm{and} 3.3 \mathrm{~km}(15 \%)$; segment C (1995-2005) $3.8 \mathrm{~km}(16 \%)$ and in segment D (2005-2015) by $1.4 \mathrm{~km} \mathrm{(5 \% )} \mathrm{(Tab.} \mathrm{1).} \mathrm{An} \mathrm{overall}$ decrease in the channel length between 1985 and
2015 was recorded (Tab. 1). In the study period between 1985-1995 a total of five segments experienced straightening as compared to eight recorded by $2005-2015$. The total length of the lower Niger River from Onitsha city to the coast changed between 1985 and 2015 (Tab. 1). In the study period, a shortening of the river was observed by $1.86 \mathrm{~km}$.

\section{Amount of river bank line shift}

\section{Period 1985-1995}

There was a substantial negative shift of the east river bank line between 1985-1995, the maximum apparently being $305 \mathrm{~m}$ at segment $\mathrm{A}$ and $\mathrm{B}$, followed by $210 \mathrm{~m}$ at segments C (Fig. 3). The west river bank line had a maximum negative shift of $241 \mathrm{~m}$ in segment G (Tab. 2, Fig. 4). Segment C experienced a substantial positive shift (deposition) of $451 \mathrm{~m}$ on the west river bank line. On the other hand, at segments F and I (Figs. 5, 6), the shift was toward the east and with more outward movement of the west bank line. In segment $\mathrm{F}$, a positive shift of $237 \mathrm{~m}$ caused a marked decrease in channel width between segment $\mathrm{E}$ and $\mathrm{F}$. Other points of narrowing took place at segments J-O (1-54 m). More cases of narrowing were observed in the assessment period than widening (Tab. 2).

Table 1

Channel length at the investigated segments of the Niger River from 1985 to 2015 showing the percentage change between the years

\begin{tabular}{|l|c|c|c|c|c|c|c|}
\hline \multirow{2}{*}{ Segment } & \multicolumn{9}{|c|}{ Length $[\mathbf{k m}]$} \\
\cline { 2 - 9 } & $\mathbf{1 9 8 5}$ & $\mathbf{1 9 9 5}$ & \% change & $\mathbf{2 0 0 5}$ & \% change & $\mathbf{2 0 1 5}$ & \% change \\
\hline A & 22.33 & 23.05 & 3.22 & 25.46 & 10.48 & 22.84 & -10.30 \\
\hline B & 23.05 & 20.83 & -9.63 & 22.81 & 9.51 & 19.51 & -14.45 \\
\hline C & 22.63 & 24.41 & 7.84 & 20.57 & -15.73 & 23.57 & 14.59 \\
\hline D & 24.94 & 26.26 & 5.31 & 26.16 & -0.39 & 24.76 & -5.37 \\
\hline E & 22.96 & 23.44 & 2.08 & 23.41 & -0.13 & 22.23 & -5.03 \\
\hline F & 22.64 & 23.08 & 1.93 & 22.98 & -0.43 & 23.29 & 1.36 \\
\hline G & 23.65 & 22.36 & -5.43 & 22.40 & 0.18 & 21.85 & -2.46 \\
\hline H & 23.29 & 22.17 & -4.83 & 22.12 & -0.19 & 23.78 & 7.5 \\
\hline I & 22.83 & 25.27 & 10.68 & 25.20 & -0.29 & 24.48 & -2.86 \\
\hline J & 22.87 & 22.17 & -3.10 & 22.11 & -0.27 & 22.31 & 0.91 \\
\hline K & 22.66 & 22.72 & 0.27 & 22.67 & -0.20 & 22.71 & 0.16 \\
\hline L & 20.57 & 20.67 & 0.50 & 20.67 & 0.00 & 22.72 & 9.9 \\
\hline M & 22.59 & 22.68 & 0.39 & 22.70 & 0.10 & 20.77 & -8.52 \\
\hline N & 22.66 & 22.90 & 1.06 & 22.83 & -0.30 & 23.05 & 0.95 \\
\hline O & 22.66 & 22.61 & -0.20 & 22.76 & - & 22.60 & -0.72 \\
\hline Total & 342.32 & 344.60 & - & 344.85 & - & 340.46 & - \\
\hline
\end{tabular}

Source: own study based on calculations on satellite imagery using GIS tools (see Figs. 2-12) 


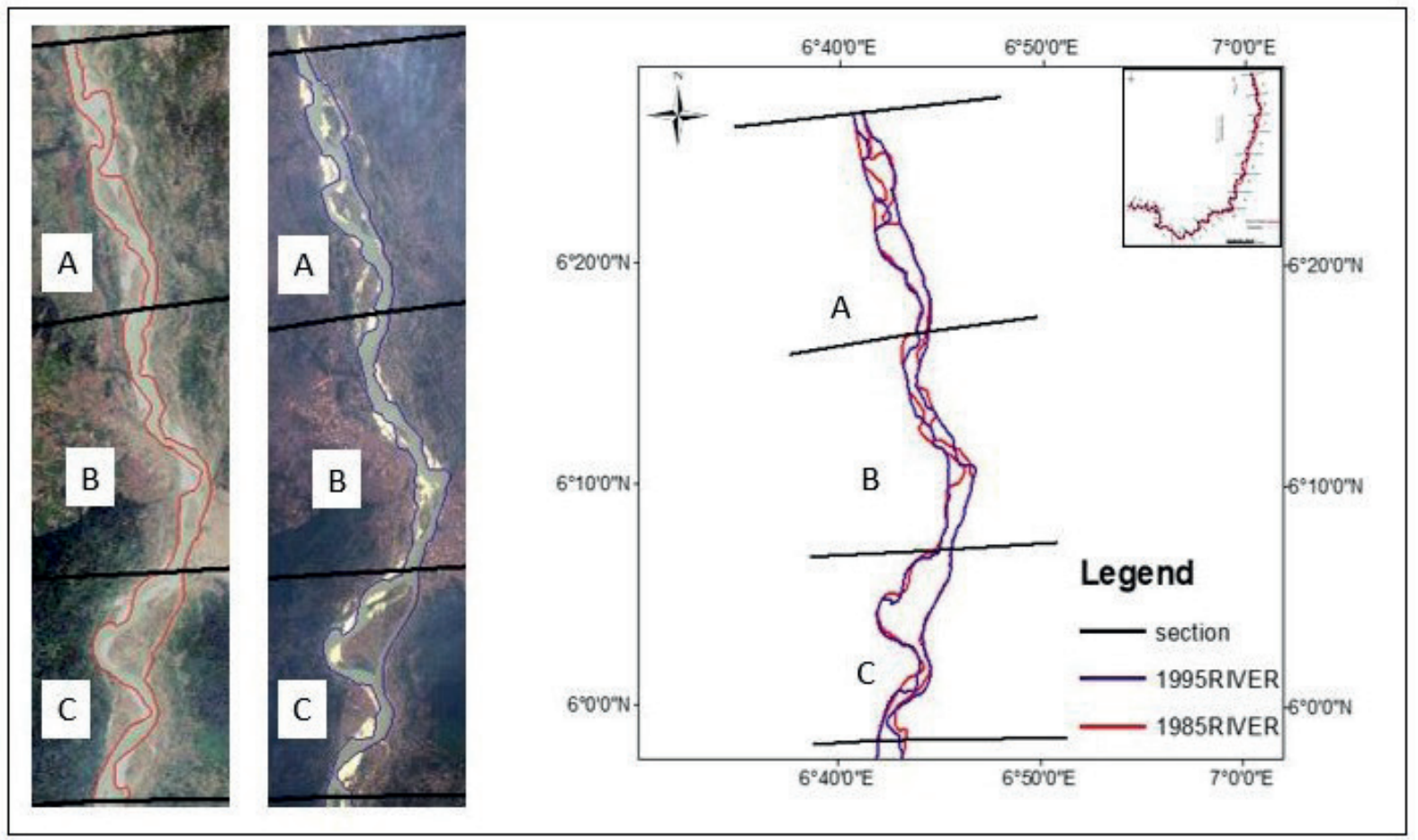

Fig. 3. Satellite imagery of the lower Niger River indicating segments A, B and C (main map); on the left-image from 1985, on the right - one from 1995

Table 2

Shift in position of river bank line [m] of the Niger River between 1985-2015; DIR-direction

\begin{tabular}{|l|c|c|c|c|c|c|c|c|c|c|c|c|}
\hline \multirow{2}{*}{ Segment } & \multicolumn{3}{|c|}{$\mathbf{1 9 8 5 - 2 0 1 5}$} & \multicolumn{3}{|c|}{$\mathbf{1 9 8 5 - 1 9 9 5}$} & \multicolumn{3}{c|}{$\mathbf{1 9 9 5 - 2 0 0 5}$} & \multicolumn{3}{c|}{ 2005-2015 } \\
\cline { 2 - 14 } & $\begin{array}{c}\text { west } \\
\text { bank }\end{array}$ & $\begin{array}{c}\text { east } \\
\text { bank }\end{array}$ & DIR & $\begin{array}{c}\text { west } \\
\text { bank }\end{array}$ & $\begin{array}{c}\text { east } \\
\text { bank }\end{array}$ & DIR & $\begin{array}{c}\text { west } \\
\text { bank }\end{array}$ & $\begin{array}{c}\text { east } \\
\text { bank }\end{array}$ & DIR & $\begin{array}{c}\text { west } \\
\text { bank }\end{array}$ & $\begin{array}{c}\text { east } \\
\text { bank }\end{array}$ & dIR \\
\hline A & 314 & -332 & E & 150 & -305 & E & 6 & -11 & E & 244 & 160 & E \\
\hline B & -351 & -461 & E & 79 & -305 & E & -11 & -45 & E & -418 & -107 & W \\
\hline C & 214 & -338 & E & 451 & -210 & E & -35 & -45 & E & -108 & -80 & W \\
\hline D & -224 & 21 & W & 613 & 139 & E & -685 & -23 & W & -153 & -119 & W \\
\hline E & -339 & -99 & W & -68 & -22 & W & -3 & -3 & E & 189 & -18 & E \\
\hline F & 76 & 345 & W & 237 & -98 & E & -19 & 2 & W & -202 & 419 & W \\
\hline G & -206 & 32 & W & -241 & -103 & W & -5 & -25 & E & 88 & 147 & W \\
\hline H & 102 & 370 & W & 89 & 105 & W & -6 & 2 & E & 20 & 229 & W \\
\hline I & 388 & -244 & E & 319 & -145 & E & 18 & -20 & E & 25 & -85 & E \\
\hline J & 20 & -53 & E & 54 & -4 & E & 1 & 18 & W & -28 & -66 & E \\
\hline K & 13 & 29 & W & 27 & 52 & W & 4 & -45 & E & -35 & 21 & W \\
\hline L & 45 & -18 & E & 27 & -21 & E & 7 & 13 & E & -2 & -11 & E \\
\hline M & -12 & -19 & E & -12 & -1 & W & 3 & 4 & E & -9 & -29 & E \\
\hline N & 42 & -16 & E & 53 & -21 & E & 18 & -2 & E & -24 & 3 & W \\
\hline O & 13 & 5 & E & -25 & -10 & W & -1 & 27 & W & 12 & -8 & E \\
\hline
\end{tabular}

Source: own study based on calculations on satellite imagery using GIS tools (see Figs. 2-12) 


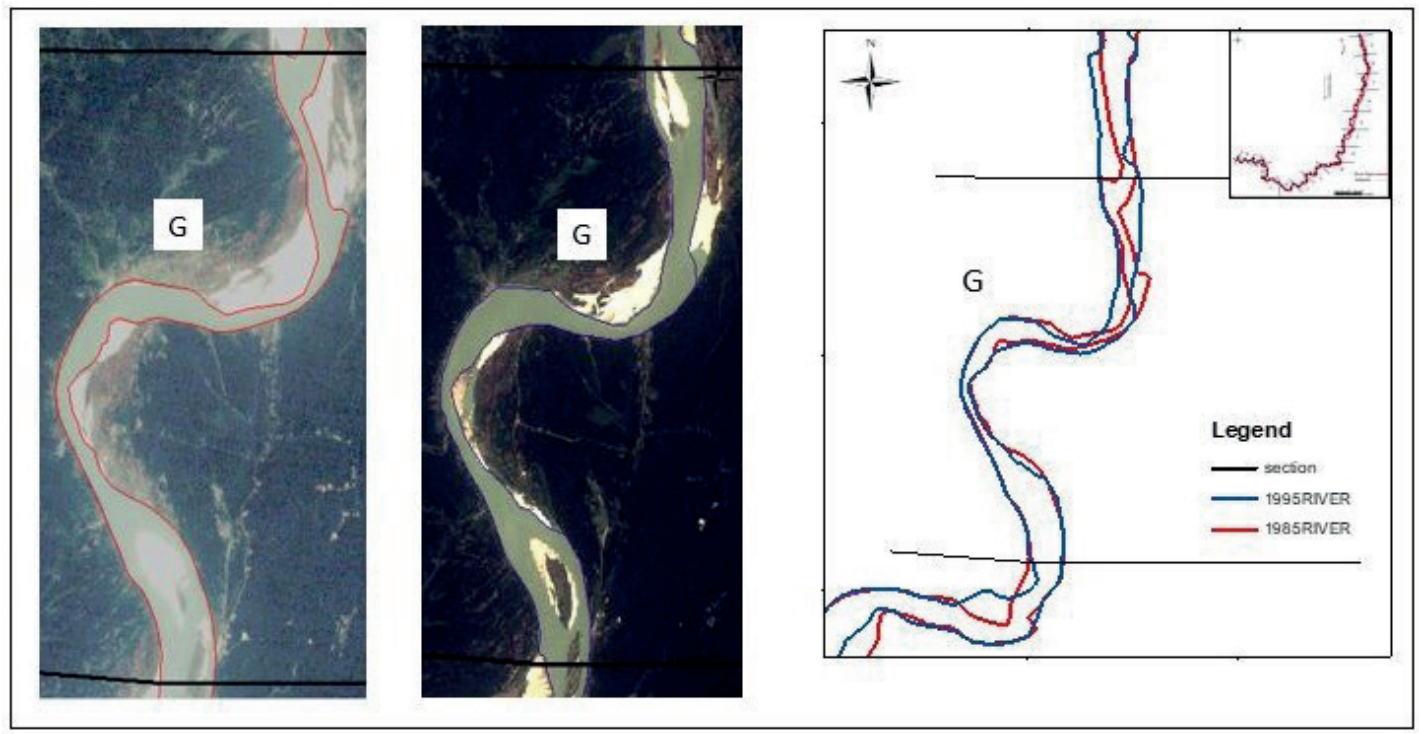

Fig. 4. Satellite imagery of the lower Niger River indicating segment G (main map); on the left -image from 1985, on the - one from 1995
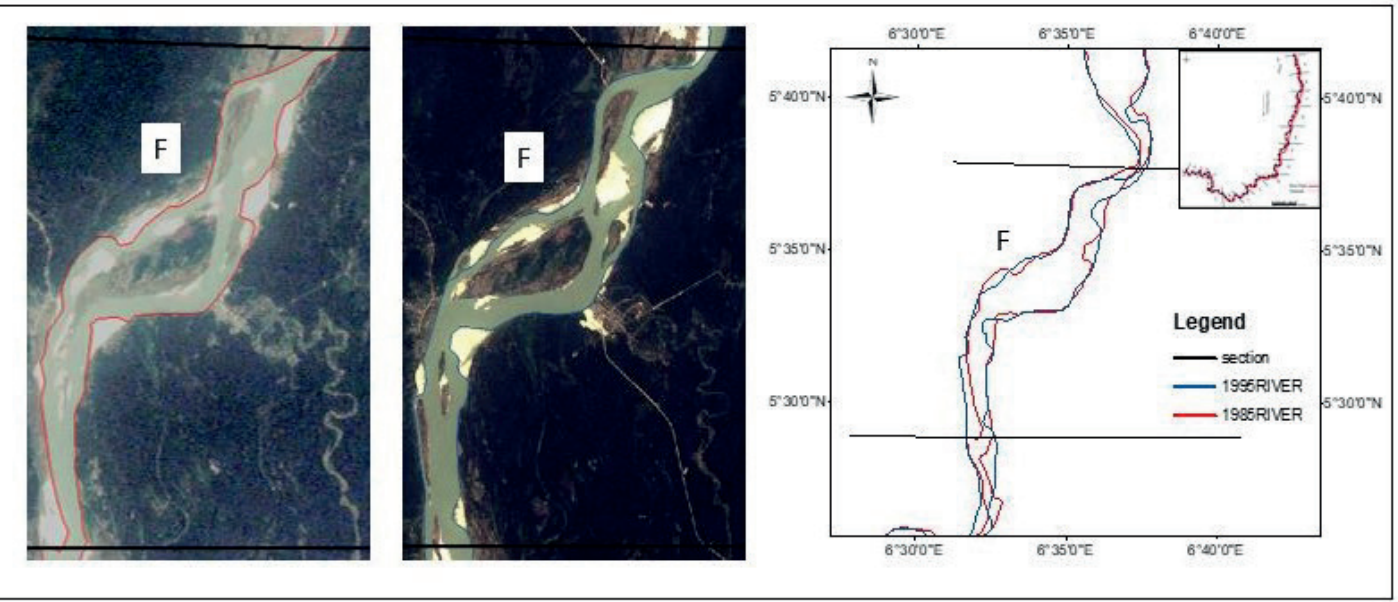

Fig. 5. Satellite imagery of the lower Niger River indicating segment F (main map); on the left-image from 1985, on the rightone from 1995

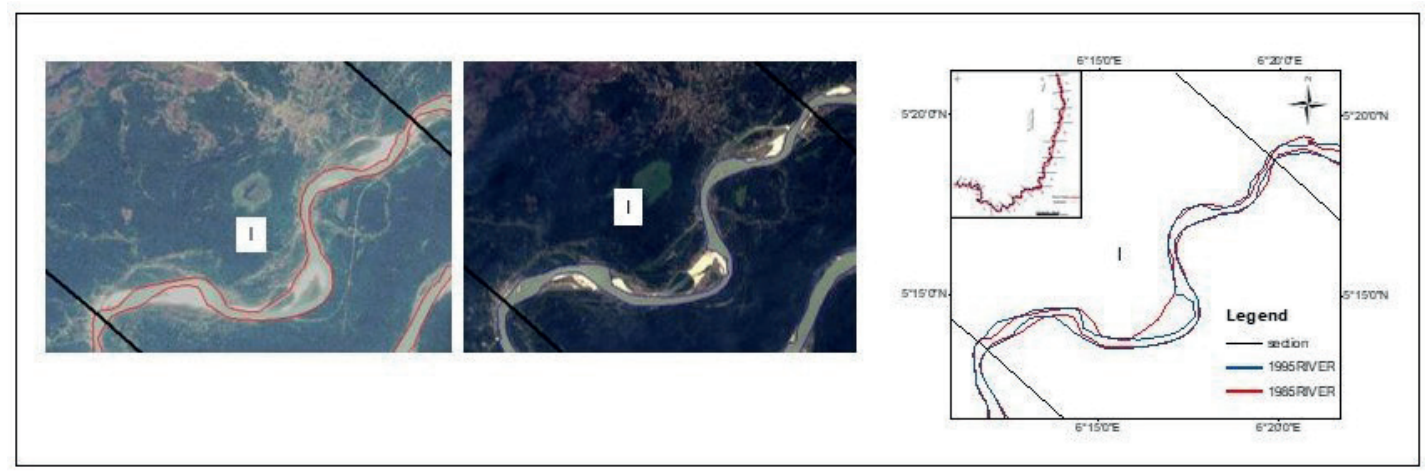

Fig. 6. Satellite imagery of the lower Niger River indicating segment I (main map); on the left-image from 1985, on the rightone from 1995 


\section{Period 1995-2005}

During the 1995-2005 period, there were instances of the negative shifting of both the east and the west river bank lines. The west river bank line saw the maximum negative shift of $685 \mathrm{~m}$ occur in segment $\mathrm{D}$. The east river bank line experienced maximum negative shifts of $45 \mathrm{~m}$ in segments $\mathrm{B}$, $\mathrm{C}$ and $\mathrm{K}$ which contributed to an increase in channel width within the channel. A maximum positive shift of $18 \mathrm{~m}$ in the river bank lines were observed in segment $J$ and segment $I$ in the east and the west river bank lines respectively. In segments $\mathrm{A}, \mathrm{B}, \mathrm{C}, \mathrm{G}$ and $\mathrm{K}$ the eastern river bank line $(1-45 \mathrm{~m})$ is observed to play a greater role in the increase of the channel width (Tab. 2).

\section{Period 2005-2015}

The west river bank line is observed to have the most frequent amounts of negative shifts as compared to the east river bank line (Tab. 2). The west river bank line shows a maximum negative shift of $418 \mathrm{~m}$ in segment B (Fig. 7) which causes a remarkable difference in the channel width between segments A-B (107-418 m).

\section{Period 1985-2015}

During this assessment period, the maximum number of negative shifts were registered by the east river bank line (Tab. 2). The east river bank line also recorded the highest value of negative shift (461 m) in segment B (Fig. 8) within the assessment period. Other notable negative shifts of the east river bank line include $338 \mathrm{~m}, 332 \mathrm{~m}, 244 \mathrm{~m}$ in segments $\mathrm{C}, \mathrm{A}$ and I respectively. The west river bank line also displayed notable negative shifts during this assessment period which include $351 \mathrm{~m}, 339 \mathrm{~m}$, $224 \mathrm{~m}$ and $206 \mathrm{~m}$ in segments B, E, D and G respectively (Tab. 2, Fig. 9). The west river bank line also recorded the highest positive shift of $388 \mathrm{~m}$ in segment I (Fig. 10), whereas the east river bank line recorded high positive shifts of $370 \mathrm{~m}$ and $345 \mathrm{~m}$ in segments $\mathrm{H}$ and $\mathrm{F}$. The minimum positive shift registered by the west river bank line was $13 \mathrm{~m}$ in segments $\mathrm{K}$ and L (Fig. 11) and by the east river bank line it was $5 \mathrm{~m}$ in segment $\mathrm{O}$ (Fig. 12).

\section{Sinuosity and length of channel changes}

Values of sinuosity oscillated considerably in the segments during different assessment periods. In 1985, six segments of the channel (G, J, K, M, N, and $\mathrm{O}$ ) were characterized by a sinuosity value of $\geq 1.5$ indicating a meandering pattern (Tab. 3). In the subsequent assessment period, the original meandering in segments $\mathrm{G}, \mathrm{J}, \mathrm{K}, \mathrm{N}$ and $\mathrm{O}$ retained their initial sinuosity values whereas segment $M$ showed an increase in sinuosity by $6 \%$.

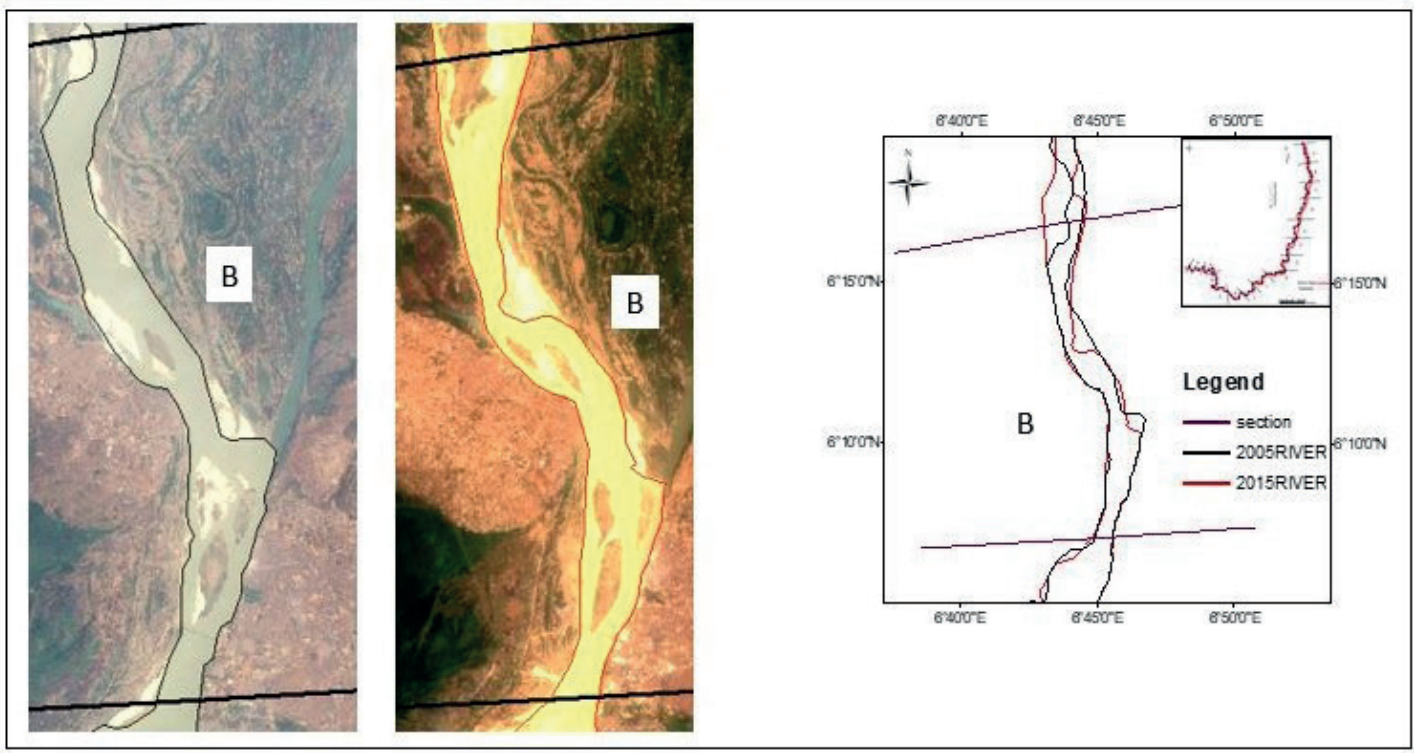

Fig. 7. Satellite imagery of the lower Niger River indicating segment B (main map); on the left-image from 2005, on the rightone from 2015 


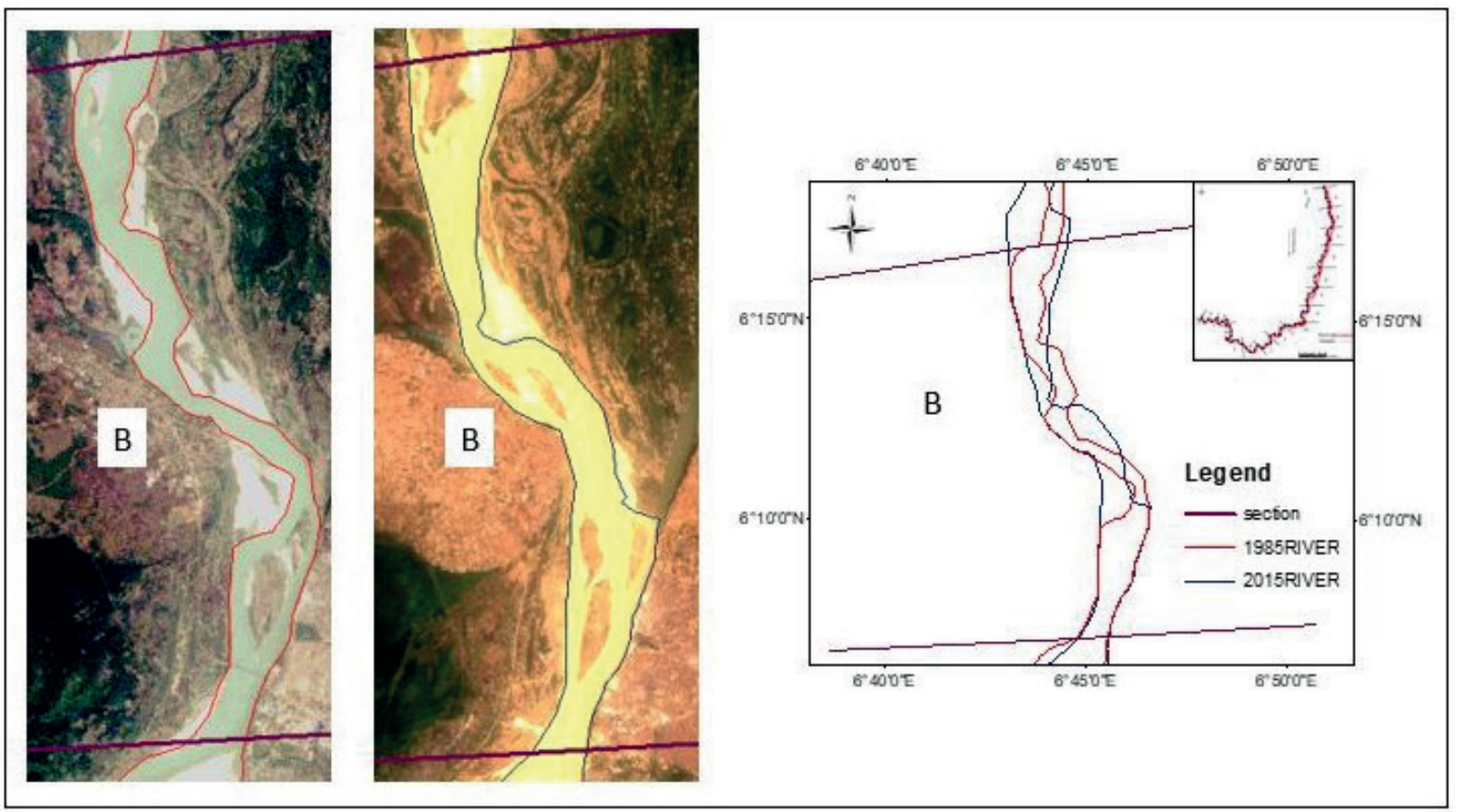

Fig. 8. Satellite imagery of the lower Niger River indicating segment B (main map); on the left-image from 1985, on the rightone from 2015

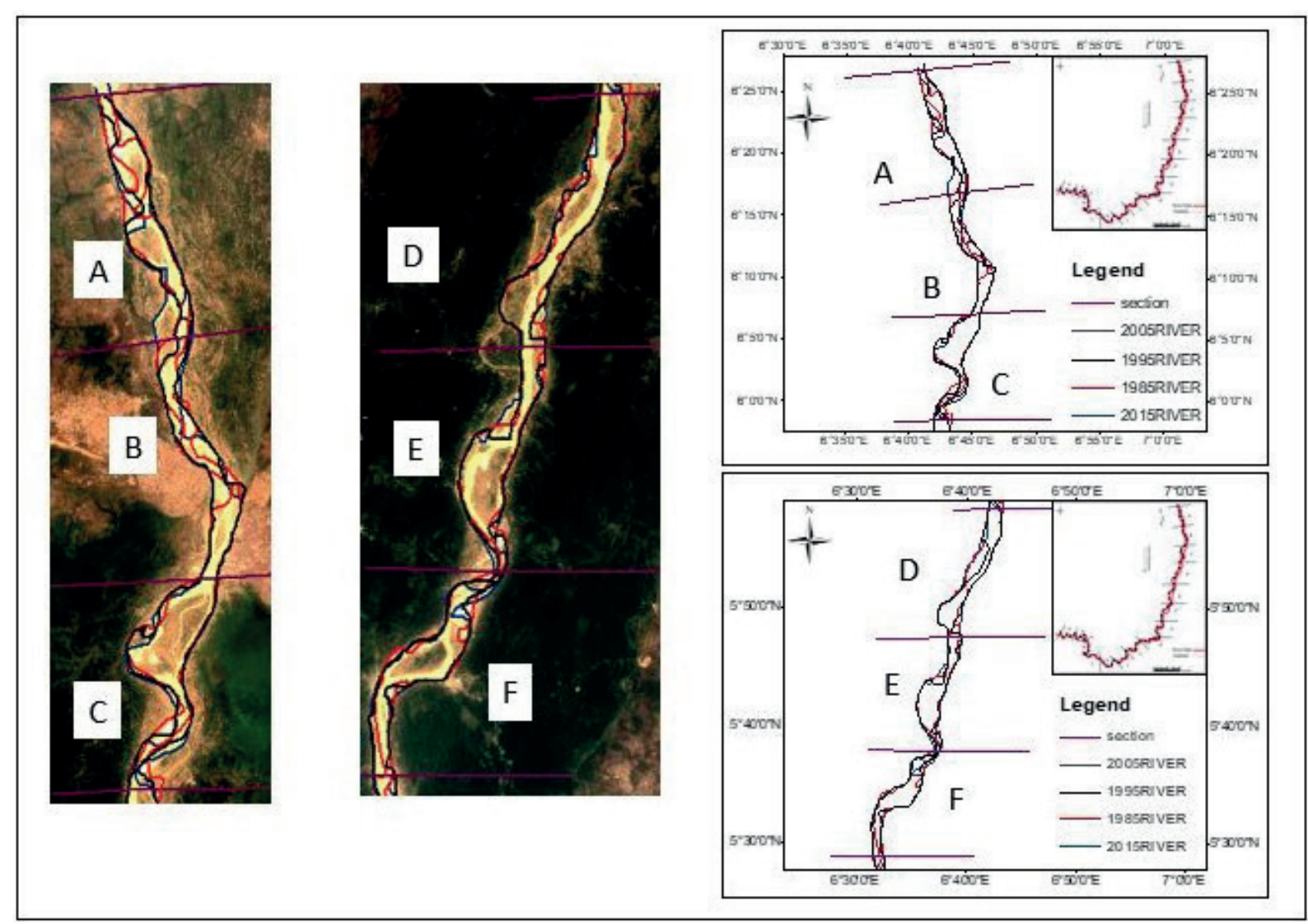

Fig. 9. Satellite imagery of the lower Niger River indicating segments A-F (main map); on the left - image from 1985, on the right - one from 2015 

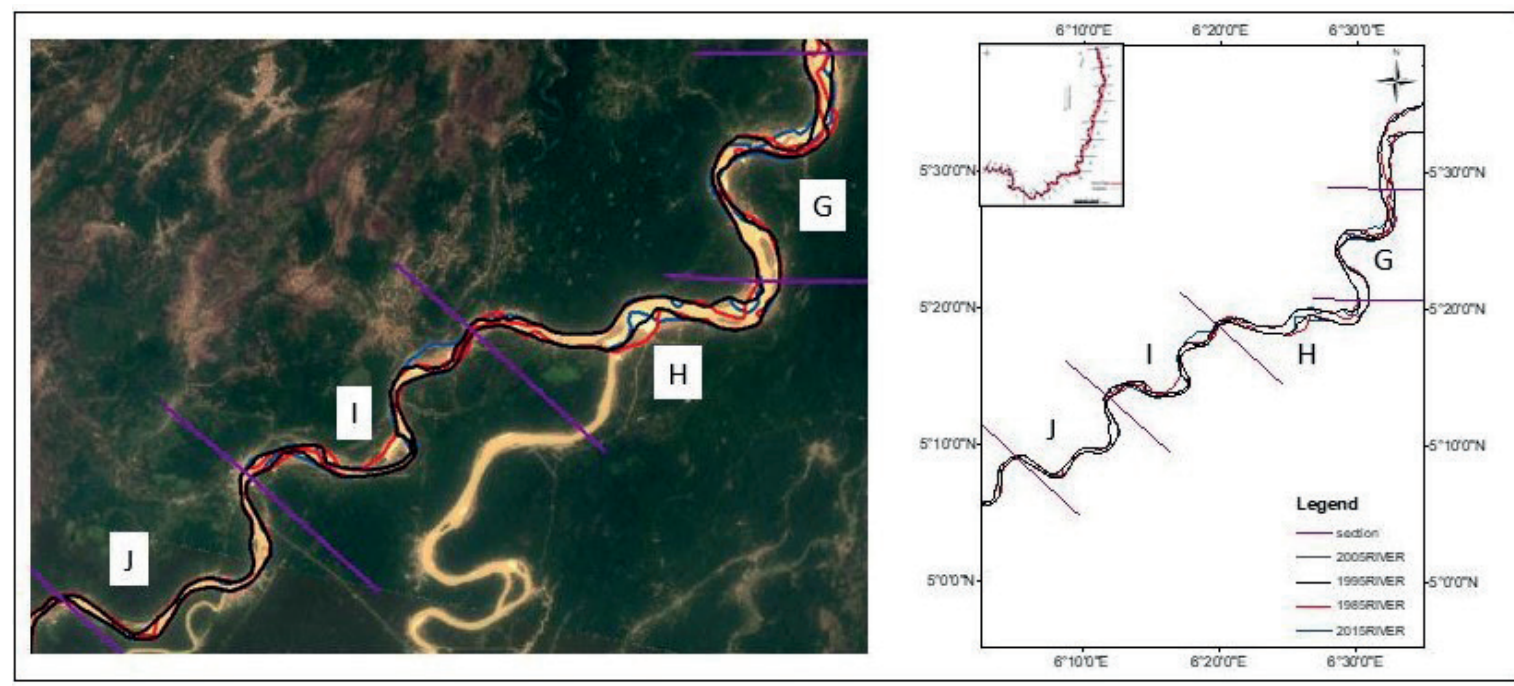

Fig. 10. Satellite imagery of the lower Niger River indicating segments G-J (main map); on the left - image from 1985, on the right - one from 2015

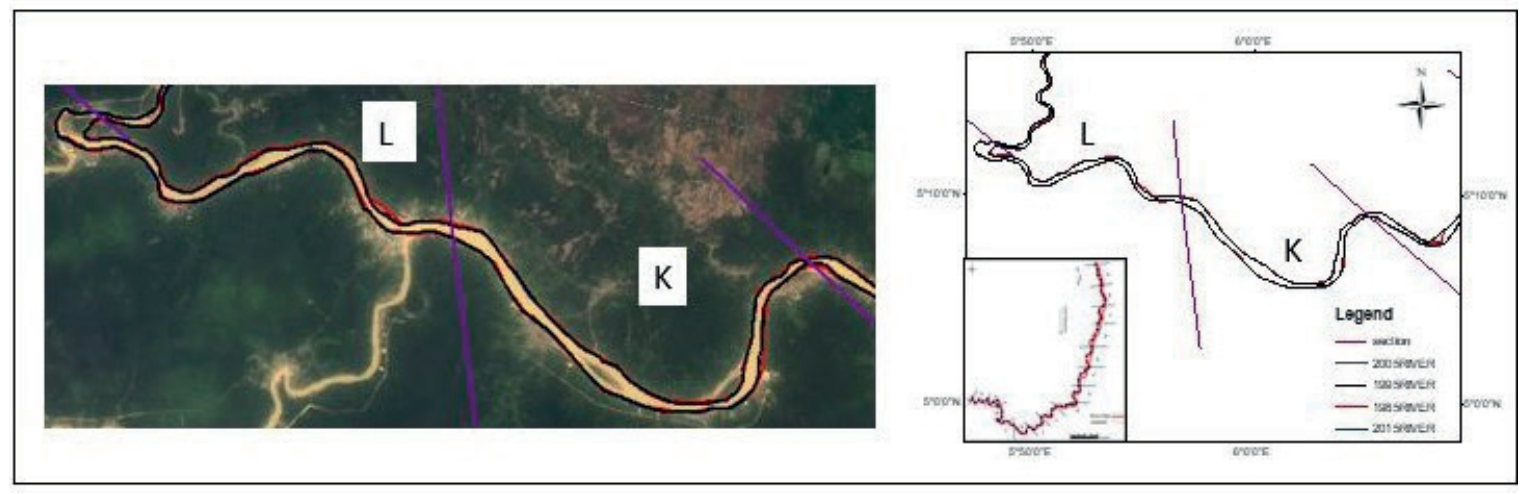

Fig. 11. Satellite imagery of the lower Niger River indicating segments K and L (main map); on the left - image from 1985, on the right - one from 2015

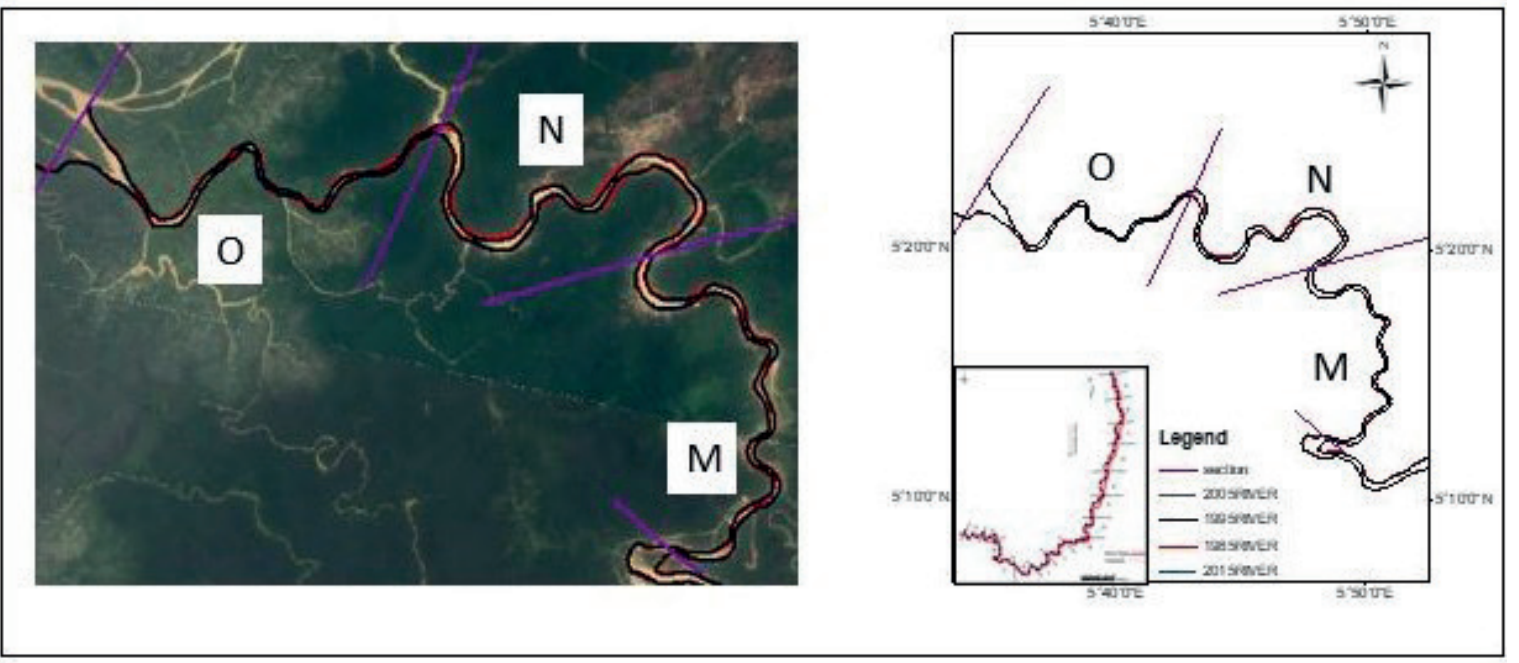

Fig. 12. Satellite imagery of the lower Niger River indicating segments $M-O$ (main map); on the left - image from 1985, on the right - one from 2015 
Table 3

Sinuosity values of investigated segments of the Niger River from 1985 to 2015

\begin{tabular}{|l|c|c|c|c|}
\hline \multirow{2}{*}{ Segment } & \multicolumn{4}{|c|}{ Sinuosity } \\
\cline { 2 - 5 } & $\mathbf{1 9 8 5}$ & $\mathbf{1 9 9 5}$ & $\mathbf{2 0 0 5}$ & $\mathbf{2 0 1 5}$ \\
\hline $\mathrm{A}$ & 1.2 & 1.2 & 1.2 & 1.2 \\
\hline $\mathrm{B}$ & 1.4 & 1.0 & 1.0 & 1.0 \\
\hline $\mathrm{C}$ & 1.4 & 1.5 & 1.5 & 1.3 \\
\hline $\mathrm{D}$ & 1.2 & 1.2 & 1.2 & 1.2 \\
\hline $\mathrm{E}$ & 1.4 & 1.4 & 1.4 & 1.1 \\
\hline $\mathrm{F}$ & 1.2 & 1.2 & 1.2 & 1.2 \\
\hline $\mathrm{G}$ & 1.6 & 1.6 & 1.6 & 1.3 \\
\hline $\mathrm{H}$ & 1.4 & 1.1 & 1.1 & 1.2 \\
\hline $\mathrm{I}$ & 1.3 & 1.4 & 1.4 & 1.4 \\
\hline $\mathrm{J}$ & 1.5 & 1.5 & 1.5 & 1.5 \\
\hline K & 1.5 & 1.5 & 1.5 & 1.5 \\
\hline L & 1.3 & 1.3 & 1.3 & 1.8 \\
\hline M & 1.7 & 1.8 & 1.8 & 1.2 \\
\hline $\mathrm{N}$ & 2.1 & 2.1 & 2.1 & 2.1 \\
\hline O & 1.5 & 1.5 & 1.5 & 1.5 \\
\hline Average & 1.45 & 1.41 & 1.41 & 1.37 \\
\hline
\end{tabular}

Source: own study based on calculations on satellite imagery using GIS tools (see Figs. 2-12)

The maximum gain, $6 \%$, was registered in segment $M$. In the next assessment period, sinuosity remained unchanged in the meandering portions of the channel. During the period of 1985-1995, the sinuosity increased in segments $C$, I and M and decreased only segments $\mathrm{B}$ and $\mathrm{H}$. The maximum registered loss was $29 \%$ in segments B followed by $21 \%$ in segment $\mathrm{H}$. The next assessment period (1995-2005) experienced no change in the sinuosity of the segments within the study area. In the assessment period 2005-2015, segments L and $\mathrm{H}$ displayed an increase in sinuosity whereas segments $\mathrm{C}, \mathrm{E}, \mathrm{G}$ and $\mathrm{M}$ recorded loss of sinuosity. The maximum loss was $33 \%$ recorded in segment $\mathrm{M}$ followed by $15 \%$ in segment $\mathrm{E}$. However, a maximum gain of $39 \%$ was recorded in segment $\mathrm{L}$ in that same year. Considering the entire stretch of the lower Niger River, changes in channel configuration led to an overall decrease in sinuosity by $4 \%$ over 30 years i.e., from 1985 (1.45) to 2015 (1.37) as revealed in Figure 2. The most significant period responsible for this loss was during 2005-2015 (see Tab. 2). The river dynamics also influenced the channel area during the different periods of assessment. The channel length ranged from a minimum of $20.57 \mathrm{~km}$ during 1985 (segment L) to $19.51 \mathrm{~km}$ in period 2015 (segment B). A maximum gain of $15 \%$ occurred during the period of 2005-2015 in segment B and C. The gain could be attributed to widening of the channel due to channel straightening. The next notable gain was recorded in the period 1985-1995 in segment I (11\%) again due to widening. The other significant gains observed in different segments were: (a) in segment A (11\% during 1995-2005), (b) in segment B (10\% during 1995-2005), and (c) in segment L (10\% during 2005-2015). Significant losses and types of shift in the position of the river bank line were recorded (Tab. 4).

\section{Table 4}

Type of shift in positions of bank line river in the Niger River between 1985-2015; DIR - direction

\begin{tabular}{|l|c|c|c|c|c|c|c|c|}
\hline Segment & $\mathbf{1 9 8 5 - 1 9 9 5}$ & DIR & $\mathbf{1 9 9 5 - 2 0 0 5}$ & DIR & $\mathbf{2 0 0 5 - 2 0 1 5}$ & DIR & $\mathbf{1 9 8 5 - 2 0 1 5}$ & DIR \\
\hline A & widening & east & widening & east & narrowing & east & widening & east \\
\hline B & widening & east & widening & east & widening & west & widening & east \\
\hline C & widening & east & widening & east & widening & west & widening & east \\
\hline D & narrowing & east & widening & west & widening & west & widening & west \\
\hline E & widening & west & widening & east & narrowing & east & widening & west \\
\hline F & narrowing & east & widening & west & narrowing & west & narrowing & west \\
\hline G & widening & west & widening & east & narrowing & west & widening & west \\
\hline H & narrowing & west & narrowing & east & narrowing & west & narrowing & west \\
\hline I & narrowing & east & widening & east & widening & east & narrowing & east \\
\hline J & narrowing & east & narrowing & west & widening & east & widening & east \\
\hline K & narrowing & west & narrowing & east & widening & west & narrowing & west \\
\hline L & narrowing & east & narrowing & east & widening & east & widening & east \\
\hline M & widening & west & narrowing & east & widening & east & narrowing & west \\
\hline N & narrowing & east & narrowing & east & narrowing & west & narrowing & east \\
\hline O & widening & west & narrowing & west & narrowing & east & narrowing & east \\
\hline
\end{tabular}

Source: own study based on calculations on satellite imagery using GIS tools (see Figs. 2-12) 
The maximum (16\%) was found in segment $\mathrm{C}$ between 1995-2005 due to straightening of the channel as a result of neck cut-off; followed by $15 \%$ in segment B during the period 2005-2015 due to loss of width. The Niger River registered an overall net loss of $1 \%$ in channel length over 30 years.

\section{Changes in the width of channel}

In addition to the reduction in channel length, there were also cases of channel widening and narrowing (Tab. 4). The period between 1985 and 1995 registered four instances of channel widening in segments $\mathrm{A}, \mathrm{B}, \mathrm{C}, \mathrm{E}$, and $\mathrm{F}$ which also represent maximum cases of channel widening in the entire time frame of the study. During the assessment periods of 1985-1995 and 2005-2015, only one and two cases of widening were recorded respectively. During each assessment period, two cases of channel narrowing were registered. The period between 1985 and 1995 registered channel narrowing in segments $\mathrm{B}$ and $\mathrm{E}$ while the period 1995-2005 registered channel narrowing in segments A and E. The last assessment period (20052015) registered two instances of channel narrowing in segments $\mathrm{B}$ and $\mathrm{E}$. Table 5 shows the channel width and average percentage of the $\mathrm{Ni}$ ger River changes in 10-, 20- and 30-year intervals. In 10-year intervals, erosion was observed of the lower Niger River (1998-1995: -43.9 m; -4\%; 2005-2015: 54.2\%; -4.7\%). Aggradation was calculated only for the first 10-year interval (19851995; $42.8 \mathrm{~m}$; 3.35\%). Other results are negative and clearly indicate erosion, varied in time (19852015: -55.3 m; 1985-2005: -1.1 m).

\section{Table 5}

Average channel width and average percentage of the Niger River changes in 10-, 20- and 30-year intervals (1985-2015); negative values indicate erosion

\begin{tabular}{|l|c|c|c|c|c|}
\hline $\begin{array}{c}\text { Lower Ni- } \\
\text { ger River } \\
\text { changes }\end{array}$ & $\begin{array}{c}\mathbf{1 9 8 5 -} \\
\mathbf{2 0 1 5}\end{array}$ & $\begin{array}{c}\mathbf{1 9 8 5 -} \\
\mathbf{2 0 0 5}\end{array}$ & $\begin{array}{c}\mathbf{1 9 8 5 -} \\
\mathbf{1 9 9 5}\end{array}$ & $\begin{array}{c}\mathbf{1 9 9 5 -} \\
\mathbf{2 0 0 5}\end{array}$ & $\begin{array}{c}\mathbf{2 0 0 5}- \\
\mathbf{2 0 1 5}\end{array}$ \\
\hline $\begin{array}{l}\text { Average } \\
\text { change } \\
{[\mathrm{m}]}\end{array}$ & -55.3 & -1.1 & 42.8 & -43.9 & -54.2 \\
\hline $\begin{array}{l}\text { Change } \\
{[\%]}\end{array}$ & -4.8 & -0.1 & 3.7 & -4.0 & -4.7 \\
\hline
\end{tabular}

Source: own study based on calculations on satellite imagery using GIS tools (see Figs. 2-12)

\section{DISCUSSION}

This study on the dynamics of the Niger River generated valuable baseline information on channel characteristics and planform changes over a period of 30 years. The variation of the width of the Niger River between study years was considered to establish the rate of erosion and deposition along its course and invariably the avulsion rate of the channel (Tab. 6). At the upper reach of the channel, erosional change is observed to be prominent as compared to the lower reach over the study period (Tab. 5). The constant increase in annual precipitation since 2005 within areas in the upper reach of the Niger River and the increase in urbanization which has led to deforestation has contributed majorly to the erosional change experienced in the area (Odjugo 2005, Abaje et al. 2015). Also, the recent constant yearly release of water from the Ladgo dam in Cameroon into the river Benue has led to the regular flooding of the study area (Azuwike \& Enwereuzor 2011), which in turn plays a part in defining the change observed within the field investigated. This periodic flooding episodes is observed to increase channel width within the study area which corresponds to findings by Beechie et al. (2006). A general widening of the channel is observed with the lower portions displaying minor erosional evidence as compared to its upper reaches. The straightening and widening of instability points in the channel upstream has caused a change in the channel gradient as well as an increase in the velocity of the river, prompting flooding downstream (see Mitra et al. 2005). Although there has also been an increase in the land use within the lower reaches of the channel, which by itself causes erosion and widening, due to the constant flooding, depositional processes rather than erosional processes are observed to expand the channel capacity. This is achieved by an increase in the number of bars and obstructions and increasing the cross-sectional area associated with the flood plain as a result of the reduction in the kinetic energy of the floods and the possible presence of manmade disturbances (Yousefi et al. 2017).

Generally, the Niger River is observed to have an increase in negative change (erosion) during the assessment period, with erosion increasing to an average of 5\% in the period between 2005-2015 
from an average of $4 \%$ in the previous years between 1995-2005 (Tab. 5). This increase maybe associated with the major flooding episode which occurred within the study area in 2012 and thus impacted the channel by the negative migration of river bank line and or development of mid-Channel Islands. This behavior is also observed in large channels like the Ganges River (Gupta et al. 2013) which are prone to regular flooding. The large amounts of positive shifts (deposition) observed in the upper reaches of the channel is due to the accumulation and deposition of flat bars, which are associated with flooding in straight - to braided rivers such as the Niger River (Masselink et al. 2017).

\section{Table 6}

Average avulsion rate of the Niger River in 10-, 20- and 30-year intervals (1985-2015); negative values indicate erosion

\begin{tabular}{|l|c|c|c|}
\hline \multirow{2}{*}{ Segment } & \multicolumn{3}{|c|}{ Avulsion rate [m·year ${ }^{-1}$ ] } \\
\cline { 2 - 4 } & $\mathbf{1 9 8 5 - 1 9 9 5}$ & $\mathbf{1 9 8 5 - 2 0 0 5}$ & $\mathbf{1 9 8 5 - 2 0 1 5}$ \\
\hline A & -40.2 & -17.3 & -6.2 \\
\hline B & 52.0 & 25.4 & -2.1 \\
\hline C & 16.6 & 4.0 & -14.3 \\
\hline D & 100.2 & 22.4 & -4.5 \\
\hline E & -40.3 & -20.5 & -4.4 \\
\hline F & -78.3 & -42.1 & -23.4 \\
\hline G & -24.6 & -12.1 & -7.2 \\
\hline H & -37.2 & -18.9 & -3.3 \\
\hline I & -33.2 & -16.2 & -9.8 \\
\hline J & -13.5 & -8.6 & -9.3 \\
\hline K & -18.8 & -8.4 & -0.8 \\
\hline L & 78.3 & 39.6 & 25.7 \\
\hline M & 46.7 & 23.8 & 15.7 \\
\hline N & 63.1 & 34.8 & -5.0 \\
\hline O & -4.6 & -5.4 & 16.6 \\
\hline Average & 4.4 & 0.1 & -2.2 \\
\hline
\end{tabular}

Source: own study based on calculations on satellite imagery using GIS tools (see Figs. 2-12)

The Niger River moved from a $4 \%$ rate of deposition at approximately $4 \mathrm{~m}$ per year within the first study period of 10 years (1985-1995) to a $5 \%$ rate of erosion at approximately $2.2 \mathrm{~m}$ per year within the last study period spanning 30 years (1985-2015) (Tab. 6). The impact of the change in land cover and an increase in the use of land surrounding the Niger River contributes to the susceptibility of the area to erosion, as an increase in settlements and infrastructure is observed during the study period. As a climatic factor, water is known to be changing worldwide and there has been growing concern as to the direction and effects of these changes on settlement and infrastructures (Adejuwon 2011) as illustrated in results established in this work, erosion is on the rise within the study area.

A notable finding of the present study was an overall decrease in sinuosity value coupled with a reduction in channel length. Analysis revealed an overall $1 \%$ net reduction in the channel length over the 30-year assessment period with the periods between 1985-1995 showing a 0.6\% increase in channel length and 2005-2015 showing a $1.3 \%$ reduction in channel length (Tab. 1). It also revealed a $2 \%$ growth in the amount of straightening in the last study period. This can be tied to the rise in flooding events within the region during the time. Mitra et al. (2005), while documenting the avulsion in lower reaches of the Sharda River in Nepal from 1780 to 2000, inferred that channel straightening is triggered by flooding characterized by high discharge and stream velocities. Mount (1995: 359-401) has also associated neck cut-off and channel straightening to heavy flooding. Thus, this increasing instability points toward increase in runoff from upstream.

The analysis distinctly revealed the eastward movement of the upper reaches of the channel during the assessment periods between 1985-2005 (Tab. 4). However, the channel is observed to be swinging back towards the west during the last assessment period 2005-2015. Generally, the upper and lower reaches of the channel is migrating eastwards whereas, the mid-section is observed to move westwards during the combined 30-year assessment period. This multidirectional shifting behavior has been observed in large rivers like the Ganges (Dhari et al.2014) and is attributed to the varied weaknesses of the channel banks at different sections of the channel. As the east bank of the lower Niger River stretch succumbs to erosion, since it is observed to be more unstable than the west bank (Figs. 3-12), the overall migration trend of the river channel is seen to be shifting eastward; this puts all flood protection structures on the east bank at high flood risk. Thus, infrastructure located in the migration directions would be at as high risk of destruction in all of the conditions observed during this study. 


\section{CONCLUSION}

The present study amply indicates that the Niger Delta Basin has undergone changes over the 30year period between 1985 and 2015 and that its equilibrium is being disturbed continuously. The significant changes correspond to increased instability in terms of the straightening of the channel and reduced channel length, decreased sinuosity (4\%) and multidirectional channel avulsion. The Lower Niger River has generally migrated toward the east, with its east river bank line being more unstable although large negative shifts of the western river bank line. These were also seen in certain segments of the channel. The maximum channel shift observed was approximately $461 \mathrm{~m}$ in the eastern river bank line over the 30 -year assessment period. The Niger River channel has experienced altered dynamics, making the future of habitats and environment within the Niger Delta precarious and potentially causing huge economic losses. Extensive deforestation, mining operations and other human activities since the 1960s in the catchment area are presumed to have severely disturbed the equilibrium of the lower Niger River System. A floodplain management plan is the need of the hour for the Niger Delta Basin which could guarantee the conservation of the river and adjacent ecologically important habitats, while minimizing risk to the inhabitants and supporting sustainable development of the floodplain.

The data presented here forms a part of the first author's PhD thesis at the Pan African University Institute of Life and Earth Sciences (PAULESI) and is sponsored by the African Union Commission through the Pan African University (PAU).

\section{REFERENCES}

Abaje I.B, Ati O.F. \& Iguisi E.O., 2015. Recent Trends and Fluctuations of Annual Rainfall in the Sudano-Sahelian Ecological Zone of Nigeria: Risks and Opportunities. Journal of Sustainable Society, 1, 2, 44-51.

Adejuwon J.O., 2012. Rainfall seasonality in the Niger Delta Belt. Nigeria. Journal of Geography and Regional Planning, 5 (2), 51-60.

Azuwike D.O. \& Enwereuzor A.I., 2011. Effect of Rainfall Variability on Water Supply in Ikeduru L.G.A. of Imo State, Nigeria. African Research Review. International Multidisciplinary Journal, Ethiopia, 5 (5), 22, 223-241.
Batalla R.J., Gomez C.M. \& Kondolf G.M., 2004. Reservoir-induced hydrological changes in the Ebro River basin (NE Spain). Journal of Hydrology, 290, 117-136.

Beechie T., Liermann M., Pollock M., Baker S. \& Davies J., 2006. Channel Pattern and River Floodplain Dynamics in Forested Mountain River Systems. Geomorphology, 78, 124-141. DOI: https://doi.org/10.1016/j.geomorph.2006.01.030.

Bridge J.S., 2003. Rivers and Flood Plains: Forms, Processes, And Sedimentary Record. Blackwell, New York.

Dhari S.D., Arya S. \& Murumkar A.R., 2015. Application of remote sensing and GIS in sinuosity and river shifting analysis of the Ganges River in Uttarakhand plains. Applied Geomatics, 7, 13-21.

FAO, 1997. Irrigation potential in Africa: A basin approach, The Niger Basin. Food and Agricultural Organization, archived 2017.07.21 at the Wayback Machine.

Goswami U., Sarma J.N. \& Patgiri A.D., 1999. River channel changes of the Subansiri in Assam, India. Geomorphology, 30, 227-244.

Gurnell A.M., 1997. Channel change on the River Dee meanders, 1946-1992, from the analysis of air photographs. Regulated Rivers: Research \& Management, 13, 1, 13-26.

Kesel R.H., 2003. Human modifications to the sediment regime of the Lower Mississippi River flood plain. Geomorphology, 56, 325-334.

Leopold L.B., Wolman G.M. \& Miller J.P., 1964. Fluvial Processes in Geomorphology. Dover Publications, New York.

Lillesand T.M. \& Kiefer R.W., 2000. Remote Sensing and Image Interpretation. $4^{\text {th }}$ ed. John Wiley \& Sons, New York.

Masselink R., Temme A.J.A.M., Giménez R., Casalí J. \& Keesstra S., 2017. Assessing hillslope-channel connectivity in an agricultural catchment using rare-earth oxide tracers and random forests models. Cuadernos de Investigación Geográfica - Geographical Research Letters, 43 (1), 19-39. DOI: http://dx.doi.org/10.18172/cig.3169.

McKnight T.L. \& Hess D., 2005. The Fluvial Processes. Physical Geography: A Landscape Appreciation. $8^{\text {th }}$ ed. Pearson, Prentice Hall, Upper Saddle River, New Jersey.

Mitra D., Anjani K., Tangri A.K. \& Singh I.B., 2005. Channel avulsions of the Sarda River system, Ganga Plain. International Journal Remote Sensing, 26 (5), 929-936.

Mount J.F., 1995. California Rivers and Stream: Conflict between fluvial Process and Land Use. University of California Press, Berkeley.

Murgatroyd A.L. \& Ternan J.L., 1983. The impact of afforestation on stream bank erosion and channel form. Earth Surface Processes and Landforms, 8, 357-369.

Odjugo P.A.O., 2006. An analysis of rainfall patterns in $\mathrm{Ni}$ geria. Global Journal of Environmental Sciences, 4 (2), 139-145.

Prasad N., 1982. Some aspects of meandering streams of the Barakar basin and their sinuosity indexes. [in:] Sharma HS (ed.), Perspectives in Geomorphology: Essays on Indian Geomorphology, 4, Concept Publishers, New Delhi, 93-101.

Reader J., 2001. Africa. National Geographic Society, Washington, D.C.

Schumm S.A., 1963. Sinuosity of alluvial rivers of Great Plains. Bulletin of the Geological Society of America, 74, 1089-1099. 
Snow R.S., 1989. Fractal sinuosity of streams. Pure and Applied Geophysics, 131 (1-2), 99-109.

Surian N., 1999. Channel changes due to river regulation: the case of the Piave River, Italy. Earth Surface Processes and Landforms, 24, 1135-1151.

Surian N. \& Rinaldi M., 2003. Morphological response to river engineering and management in alluvial channels in Italy. Geomorphology, 50, 307-326.

Tiegs S.D. \& Pohl M., 2005. Planform channel dynamics of the lower Colorado River: 1976-2000. Geomorphology, 69 (1), 14-27.

Vanacker V., Molina A., Govers G., Poesen J., Dercon G. \& Deckers S., 2005. River channel response to short-term human-induced change in landscape connectivity in Andean ecosystems. Geomorphology, 72, 340-353.
Ward P.D., Montgomery D.R. \& Smith R., 2000. Altered river morphology in South Africa related to Permian-Triassic extinction. Science, 289 (5485), 1740-1743.

Wellmeyer J.L., Slattery M.C. \& Phillips J.D., 2005. Quantifying downstream impacts of impoundment on flow regime and channel planform, lower Trinity River, Texas. Geomorphology, 69, 1-13.

Winterbottom S.J., 2000. Medium and short-term channel planform changes on the River Tay and Tummel, Scotland. Geomorphology, 34, 195-208.

Yousefi S., Mirzaee S., Keesstra S., Surian N., Zakizadeh R. \& Tabibian S., 2017. Effects of an extreme flood on river morphology (case study: Karoon River, Iran). Geomorphology, 304, 30-39. 